interference, in a manner similar to Kœnig's well-known apparatus for that purpose, constructed on the method of Wheatstone.

JOHN G. MCKENDRICK

\section{THE GEOLOGICAL SURVEY OF NEW. FOUNDLAND}

Di UE no ice of the Report for 1874 , of Mr. Murray, the Director of the Newfoundland Geological Survey, has been delayed until the appearance of the map and sections referred to in that Report. These we have now received, and as they deserve more than ordinary attention from geologists, we propose to give some account of the recent work of the Survey. The able and indefatigable Director, who, like his late chief, Sir William Logan, has grown grey in the service of the Dominion, divides his Report into two parts, one of which narrates his own labours during 1874, while the other is furnished by his assistant, Mr. J. P. Howley, of whose surveys for the same period it gives the main results. Mr. Murray's Report is marked by that quiet practical good sense which formed so characteristic a feature of his contributions to the Canadian Geological Survey. It is more occupied with plans and advice for opening up the country to settlers, and developing the great resources of the island in timber and as a cattlegrazing district, than with geological matters. The latter are treated, too, with an eye to future mineral industries Mr. Murray, in short, is doing the solid and useful work of pioneering. That work may make no brilliant display at the time, but if, as he hopefully anticipates, there is a prosperous future before Newfoundland, the colonists will look back upon his labours as those which largely guided and stimulated that prosperity.

But Mr. Murray is too true a geologist to let any chance escape him of advancing the purely scientific treatment of geology. And he is fortunate in possessing in $\mathrm{Mr}$. Howley a geologist who can carry out his views with admirable skill. From Mr. Howley's Report and Map geologists in other countries will learn some particulars not only important as regards the geology of the colony, but of general interest as bearing on the question of the nature and modus operandi of the metamorphic action to which the origin of such rocks as dolomite and serpentine is attributed.

Mr. Howley's labours during 1874 were, in accordance with Mr. Murray's plans, given to the survey, topographical and geological, of the western coast of $\mathrm{New}$ foundland, about the peninsula and bays of Port-a-Port, and St. George's Bay. In tracing the Lower Silurian formations of the Newfoundland coast, Mr. Murray and his colleagues have been abie to identify them with more or less precision as equivalents of the Quebec and Birdseye and Black River groups of Canada. But in the course of their surveys they have at different times encountered intercalated sheets of metamorphic rocks in the Lower Silurian series overlying uraltered and fossiliferous strata. Thus at Bonne Bay, in 1862, Mr. Richardson found highly metamorphosed rocks, including white talcose slates and serpentine, in some portion apparently of the Quebec group. Four years afterwards Mr. Murray observed further south, in the Bay of Islands, that sandstones believed to represent the Sillery zone of the Quebec group passed below the serpentine of the Blowmedown mountains. Mr. Howley has now confirmed and extended these observations by mapping the country between the Bay of Islands and St. George's Bay. He has traced Mr. Murray's serpentine rocks southwards to Bluff Head, and finds that they pass unconformably over different horizons of rocks which are taken to represent the Sillery and Levis subdivisions of the Quebec group of the Lower Silurian system. The striking character of this unconformable junction is well brought out upon the map, where two large cakes of the overlying rocks are seen to sweep over both anticlinal and synclinal folds of the lower formations. These cakes consist of brecciated dolomite or limestone, chlorite-slate, diorite, and serpentine, having a total thickness of perhaps 1,500 feet. Their exact geological horizon seems not yet quite satisfactorily fixed, but they are placed provisionally between the Sillery and Birdseye and Black River formations. Doubtless further details will be given in future reports regarding this remarkable feature of Newfoundland geology, and till they appear it may be well to avoid any discussion of the theoretical aspect of the subject. It is not the first time that an instance has occurred of the higher rocks of a district being more metamorphosed than the lower. but there has probably never been observed so remarkable a case, for here the metamorphosed and contorted series is described as actually overlying unmetamorphosed strata.

Other questions of interest occur in the Report. Thus a centre of pre-carboniferous volcanic action is indicated as existing along a line north of Fox Island and on the coast to the south head of the Bay of Islands. The coalmeasures, of which a few patches occur in the district surveyed, overlap from the Millstone Grit on to the Carboniferous Limestone. The latter formation contains, according to Mr. Davidson, brachiopoda which all belong to well-known British species. In another respect there is a curious analogy between the base of the Carboniferous system in Newfoundland and in some parts of Britain. In the former country the lower nembers of that system consist largely of red and green sandstones, clays, and conglomerates, with traces of plants, beds of gypsum, and occasional limestones full of ordinary Carboniferous Limestone fossils. Anyone who has looked as the base of the Carboniferous system in Cumberland, Westmoreland, Dumfriesshire, and other parts of Britain, will recognise these lithological features as characteristic also in this country. It would seem that the same physical conditions preceded the deposition of the Carboniferous Limestone on both sides of the Atlantic-inland seas or lakes, not far separated from the sea, in which red sediment with gypsum and occasionally common salt was laid down, but which were not usually well suited for the support of molluscan life, though liable now and then to inroads of the sea outside and to invasions of mollusca, corals, and other marine forms.

The map, on a scale of four miles to an inch, is evidently a piece of most careful work. It shows the arrangement of the rocks from the Laurentian group up to the Coal-measures, though, partly from vast unconformabilities and partly from faults, great portions of the geological series are not represented in this part of $\mathrm{New}$ foundland. It may be mentioned, in passing, that the largest fault traced on the map-that which flanks the Laurentian range from Table Mountain north-eastwards to Grand Pond-is not coincident with the line of any river, but is crossed by all the chief rivers and brooks in the district which it traverses. Hence the same relation between fracture and erosion exists there which has been so extensively traced and keenly discussed in this country. To the completion of this important map geologists will look forward with not less interest than must be taken by those who see in the labours of Mr. Murray and his associates one of the best pledges for the carly development of the colony.

A. $G$.

\section{THE ANCIENT BRITISH PIG}

PROF.ROLLESTON has recently been making some researches on swine, the discovery of some remains buried in the alluvium, near Oxford, having directed his attention to the subject. In illustration of a paper "On the Prehistoric British Sus," read by him at the Linnean Scciety, June 15, the following specimens were exhibited :-I. Skull of Suts scrofa, var. domesticus, from a late Celtic interment. 2. Skulls of Sus scroja, var. ferus, from 